J O U R A L O F

French and Francophone Philosophy
REVUE DE L A

philosophie française et de langue française

\title{
Anticipatory Imagination in Aging: Revolt and Resignation in Modern Day France
}

Jill Drouillard

Journal of French and Francophone Philosophy - Revue de la philosophie française et de langue française, Vol XXIV, No 3 (2016) 56-73.

\author{
Vol XXIV, No 3 (2016) \\ ISSN 1936-6280 (print) \\ ISSN 2155-1162 (online) \\ DOI 10.5195/ jffp. 2016. 787 \\ www.jffp.org
}

\section{(c) EY-NC-ND}

This work is licensed under a Creative Commons Attribution-Noncommercial-No Derivative Works 3. 0 United States License.

\section{UILIS D-Sunt}

This journal is operated by the University Library System of the University of Pittsburgh as part of its D-Scribe Digital Publishing Program, and is co-sponsored by the University of Pittsburgh Press 


\title{
Anticipatory Imagination in Aging
} Revolt and Resignation in Modern Day France

\author{
Jill Drouillard
}

Université Paris-Sorbonne IV

“Rien n'arrive ni comme on l'espère, ni comme on le craint. Nothing really happens as we hope it will, nor as we fear it will."1 Améry appropriates this quote of Proust to highlight how our imaginative powers can never approach its reality during an extreme event. This failure of what he coins our anticipatory imagination is depicted in his phenomenological account of torture, an event whose extremity is later compared to another embodied experience: that of aging. Equating torture with aging may seem shocking to some, and Améry was critiqued for suggesting such a parallel, particularly since he narrates a lived experience with the latter at the mere age of fiftyfive. He revisits this critique in the preface to the fourth edition of On Aging: Revolt and Resignation where he states:

Today as much as yesterday I think that society has to undertake everything to relieve old and aging persons of their unpleasant destiny. And at the same time I stick to my position that all highminded and reverential efforts in this direction, though indeed capable of being somewhat soothing- are still not capable of changing anything fundamental about the tragic hardship of aging. [Améry's emphasis] ${ }^{2}$

The "today" of society that Améry referenced was 1977. But what about today? Is Améry correct in projecting that despite our best efforts nothing fundamental can change the quite unbearable experience of aging? Are attempts to aid the aging complicit in a "vile dupery" that ends in "metaphorically empty" phrases such as "rest in peace" ?3 I would like to pose these questions in the wake of a heated debate in France regarding the legality of assisted suicide for aging persons (Améry took his own life and sees suicide as an acceptable form of revolt and resignation, the only authentic choices left to the aging). Thus, this paper seeks to not only dissect his account of aging (and the failure of anticipatory imagination in futural 
projections of it) but to ask whether his philosophy could be read alongside current French thinkers to better assess comment mourir dans la dignité.

\section{A Historical Context}

Though this article is not an empirical study on current statistics regarding suicide rates among aging persons, I do find it necessary to reference some figures for the sake of placing Améry's work within a modern context. Almost fifty years later his work is still not only relevant for approaching the topic, but his existential and phenomenological take on the matter is perhaps the only aspect missing from current debates on the legality of assisted suicide. Each year, around 3000 citizens over the age of 65 take their own life in France, a figure not to be neglected insofar as aging persons make up $20 \%$ of the population yet account for $28 \%$ of all suicides. ${ }^{4}$ This ever-increasing number gained a lot of media attention in 2013 after two octogenarian couples opted to take their lives within days of each other. One couple, Georgette and Bernard, referred to as "les amants de Lutetia", chose to die together via asphyxiation by placing plastic bags over their heads. This gesture of double suicide was accompanied by a letter that expressed their indignation at not being able to die with dignity; French law deprived them of une mort douce. Georgette laments, "La loi interdit l'accès à toute pastille létale qui permettrait une mort douce. (...) De quel droit contraindre (une personne) à des pratiques cruelles quand elle veut sereinement quitter la vie?" 5 Here I should acknowledge the crudeness of the above statement, "[They] chose to die together via asphyxiation by placing plastic bags over their heads." Noticing the vulgarity and directness of this statement, I at first tried to rephrase it, though there is nothing subtle about their actions. Their death was not soft. The French media has perhaps done this couple injustice by turning their act of revolt into a mere love story. Describing the way in which the couple was found dead, an article quotes a chanson by Edith Piaf, "On les a trouvés se tenant par la main, les yeux fermés vers d'autres matins". ${ }^{6}$ Are there other mornings to come? Does romanticizing their act of rebellion act as a consolation for the rest of society? Do we look at their political act with nostalgia so as to assuage our own fears of aging? Of course, the fact that they were lovers is not negligible, but it ignores the real significance of their protest. Recounting the story that they were lovers found dead, hand in hand, dismisses the point that their deliberate act to die in that hotel, on that day, together, was the last authentic choice made by them.

According to Améry, death does not save the future as a dimension of time. Death is "my being taken out of space in the most literal meaning of the word: my an-nihilation". ${ }^{7}$ There are no more mornings to come. To speak of other mornings is as absurd as speaking of aging as the "autumn of life". Améry exclaims, "We speak of the 'autumn of life'- charming metaphor! Autumn? After autumn comes a winter, after that once again a 
spring and then a summer. For the aging, however, the autumn of life is the last autumn and therefore not an autumn at all" .8 In the face of this final harvest, few possibilities are left. Yet, this is not because the elderly are running out of time. Here is perhaps Améry's greatest perspicacity on the experience of aging: the future is not time, but world and space. He notes,

Those who believe they have what is called 'time' in front of them, know that they are truly destined to step out into space, to externalize themselves. Those who have life within them, i.e. authentic time, have to be internally satisfied with the deceptive magic of memory. What is in store for them is death [Améry's Emphasis]. ${ }^{9}$

Thus, is this last autumn just a being-towards-death? Yes and no, he replies, with an emphasis on the "no". One cannot wait for something that is nothing. Waiting for death becomes as absurd as waiting for Godot. In this sense, choosing to lay a hand on oneself10 is one of the only authentic choices left when faced with the imminence of death (of nothing). Thus, for les amants de Lutetia, their last actions were imbued with much significance. They chose their time, space, and company in death. These were possibilities still left in the world, a world increasingly retracting from them. The hotel Lutetia was symbolically chosen, because after the war, it had been a safe haven for those returning after deportation, including Georgette's father with whom she was reunited there. How important is it for us to choose our last place of dwelling? Damien Le Guay, philosopher and president of the comité national d'éthique du funéraire, opposes the legalization of assisted suicide, noting that the majority of France is only in favor of this practice because of their fear of dying in hospitals. He states:

Encore faut-il savoir pourquoi les Français veulent l'euthanasie? Avant tout, ils craignent l'hôpital! Ils n'ont pas envie de mourir seuls, abandonnés, face à des machines, réduits à leurs maladies et incapables de comprendre la logique toute puissante des médecins(...)Aujourd'hui $70 \%$ des Français meurent dans une structure hospitalière, parfois dans des conditions indignes et de temps à autre, dans des circonstances sordides. ${ }^{11}$

Would the problem of "le mal mourir" in France be resolved if those at the end of their days were able to die at home? But, what does that home look like? Le Guay notes, "Au début des années 1960, 70 \% des français mourraient chez eux". However, today, aging persons are increasingly put in retirement homes (les maisons de retraite). Retraite: to retract oneself from an active life. Or, as Amery would have it- retraite: to have the world retract from you.

Rather than quietly watch their world dissipate, Georgette and Bernard decided to take matters into their own hands. They wanted to die an intimate death together, rather than be surrounded by unknown nurses and alienating machines. Their decision to die was resolute, and they made 
the circumstances of their death matter. Instead of passively waiting to die, was their voluntary death their last act as autonomous agents? This question is not meant to solicit a reply in favor of suicide. It is, however, an interrogation that seeks to think about the experience of aging and the option of assisted suicide, all the while knowing that a clear understanding of both is impossible. As Barlow emphasizes in his translator's introduction to On Aging, "[Améry] is not trying to convert or teach morality. The key to Améry's book is his determination to look at the phenomenon of aging without blinking." Here, I think of Nietzsche, "'We have invented happiness', say the last men, and they blink."12 Améry does not want us to take solace in a false community of happiness, but rather to look at the inevitable experience of aging dead on. We place the aging in retirement homes, and then, we blink. We incite them to take part in activities that serve no purpose but act as distraction, and then, we blink. What is disconcerting is that, for the most part, those who are dealing with current legislation to increase the happiness of the aging, and those who are creating the rhetoric that defines what it means to die in dignity are not themselves aging. Amery reiterates à plusieurs reprises that, existentially, one can never know what aging is like until one experiences it. Thus, how can we anticipate this experience before its occurrence? The act of imagination is paramount to individual freedom insofar as futural projection allows one to anticipate a potential experience and then choose from different possibilities of action. How can we appropriately anticipate aging, a condition that certainly ends in death, which is no possibility at all? How can we possibly imagine our reaction in the face of such annihilation? Anticipatory imagination is not possible when projecting the event of aging, "but not because the occurrence, as one says, perhaps 'goes beyond the imagination' (it is not a quantitative question), but because it is reality and not phantasy."13 The failure of anticipation is key here. Michèle Delauney, minister responsible for the well being of aging persons, "a pour mission de préparer une loi 'd'anticipation et d'accompagnement de la perte d'autonomie.'"14 How can one anticipate the loss of autonomy as experienced by an(other)? Here, our imagination fails. Now, I do not wish to insinuate that we should stop trying to foresee a better future for the aging. However, I do think Améry's insights, developed after listening to the stories and experiences of the elderly can help us here. We should particularly revisit the decision of aging persons to take their own lives within a current French climate that continues to criminalize assisted suicide.

In On Suicide, Améry claims that turning thoughts of suicide into a sign of illness that can be cured with psychology fails to recognize the value in an individual's own interpretation of his/her life. Emphasizing the difficulty inherent in trying to understand one's motivation in committing suicide, he states, "One is trying to understand reasons expressed in a language that is individually subjective." 15 How can an aging person contemplating suicide verbalize thoughts that are intersubjectively 
incoherent? Language fails in trying to convey an experience that is most one's own. An individual's thoughts thus become translated into medical terms that psychology can diagnose. Rather than approach the issue of aging without blinking, the absurdity and contradictory nature of the experience is reformulated into wording that the rational mind can digest. "We have invented happiness", say the psychologists, and they blink. Testimonies from experts appear to diagnose the condition of aging as one of depression for which a cure could be found within the medical community. "Le suicide des personnes âgées est quasiment à 100\% lié à la depression [emphasis mine]"16, states Marie-Claude Frénisy, a psychologist in Dijon. Quasiment? That's a pretty bold statement. Geriatrician Olivier Henry estimates that “40\% des personnes qui passent dans son cabinet prennent des antidépresseurs...La dépression est l'une des pathologies les plus fréquentes à cet âge-là. L'avenir est limité, l'horizon se rétrécit." The future is limited. The horizon is retracting. In the face of these two brutal facts about aging, is the solution medication? Is giving antidepressants to aging persons the solution to their ever-increasing loss of autonomy? Is this not just a case of the nonaging imposing their will upon the aging? Is it our way of saying that the value they ascribe to their lives is not compatible with the rest of the world's instinct to live? Why do we seek to keep the aging in a world that is continually retracting from them?

Retraite: the fact of having retracted oneself from an active life. Does one retire, or does the world retire from them? What does that mean to retract oneself from an active life? Are our activities not central to our formation of self? Upon meeting someone for the first time, the defining question is "What do you do?" This inquiry is largely aimed at assessing one's vocational activity, but extends to other questions about one's hobbies/interests (basically, what one does out there in the world). In their book Philosophie des âges de la vie, Éric Deschavanne and Pierre-Henri Tavoillot address the need to rethink the different ages of a person's life within a modern historical context where certain markers of maturity are no longer clearly delimited. The prolongation of our expected life span poses important economical questions, concerning l'emploi des seniors, and if and how we should in turn prolong the age of retirement. In addition to burgeoning financial problems, a reconfiguration of retirement in France raises questions of a political and social nature. Deschavanne and Tavoillot assert, "La retraite à 60 ans apparut comme une grande victoire sociale, l'aboutissement historique des grandes luttes des XIXe et XXe siècles."17 Once heralded as a victory for allowing a tranquil retirement after having paid one's dues as a contributing member of society, the arbitrariness of this age now becomes salient as "pour le dire clairement, à 60 ans, l'individu n'est pas fini." 18 One can expect to live another 20 years after retirement. The logistics of financial planning aside, how is one supposed to occupy one's space in the world for an additional two decades? Deschavanne and Tavoillot call for the necessity of rethinking a politics of aging, one that 
accounts for the changing nature of retirement. This stage of one's life is no longer about financial compensation for services rendered but is an issue of épanouissement personnel. How can society assist in the personal development and well being of aging persons? Comment bien vieillir? One of the final sections of Philosophie des âges, "Aider l'entrée dans la vieillesse", suggests that current debates on how to "age better" focus on the continuation of maintaining some form of activity. They state that whether or not the issue at hand is economical or social, the conviction remains that:

le meilleur moyen d'entrer dans la vieillesse et de la vivre au mieux consiste à maintenir un lien avec une activité. L'activité peut être salariée, bénévole, associative ou même de loisir, mais elle reste la garantie du 'bien vieillir' [Deschavanne and Tavoillot's emphasis]. ${ }^{19}$

Is remaining active the key to bien vieillir? Or, does it just seem that way to others occupying the world? Claude and Odette is another octogenarian couple that decided to take their own lives; like Georgette and Bernard, they left a letter explaining the motivating factors behind their decision. During interviews conducted after the incident, a neighbor commented, "Ils allaient au marché et au théâtre," perhaps hinting at the incredulity of their actions. How could this happy active couple do such a thing? A key term, floating around in ethical debates that try to understand the volition of assisted suicide is the notion of mal mourir. Reacting to the actions of these two octogenarian couples, Noëlle Chatelet states, "Je pense que la mort s'apprend. Seulement on a du mal à le faire dans un pays où elle est déniée. Ce qui fait peur aux personnes de cet âge, ce n'est pas de mourir mais de mal mourir."20 But, what does it mean to say that someone dies poorly? What criteria would have to be met to ensure that someone dies better? Chatelet, whose own mother Mireille Jospin a choisi la mort, emphasizes the importance of being able to choose the conditions under which we depart from this world. As previously enunciated, Georgette and Bernard, as well as Claude and Odette, made the circumstances of their death matter. They decided the time, place, and company of their death, their only regret being the inaccessibility to une mort douce, because of current legislation regarding assisted suicide in France. Chatelet emphasizes the significance of ceremony in the arrangement of their deaths:

C'est ce qui rend la chose si belle. C'est une cérémonie pour euxmêmes qui met en scène leur amour pour toujours. Ce sont des amants jusqu'au bout. C'est une mise en scène pour nous aussi, la société et le législateur, qui veut dire : 'aider à partir ceux qui veulent partir'21

Chatelet's statement is important, because while she recognizes their love for each other and their choice to create a scene that "immortalizes" it, she also notices the political significance of their actions. Should the French government help those who wish to leave (the world)? Is the option of 
assisted suicide an appropriate solution to le mal mourir? Would having the possibility to choose une mort douce help those who are aging better cope with their retraction from the world? Even though one does not fully appreciate the act of aging until its occurrence, would the anticipation of this event be met with less apprehension, if the potentiality for a softer, chosen death were possible? Nietzsche states, "The thought of suicide is a powerful comfort: it helps one through many a dreadful night." 22 Would the option of assisted suicide be an even more powerful comfort, helping those through the process of aging? An article titled Se suicider au grand âge : l'ultime recours à une vieillesse déchue? by Arnaud Campéon suggests that it would. Here, he elucidates on l'idéation suicidaire par anticipation in which aging persons (belonging to one of two groups) project themselves into a future where their conditions of living are deemed no longer acceptable. While the first group of people contemplates suicide in anticipation of an eventual senility, the second group envisages a future where their disconnection from the world and others negates the value that they ascribe to their existence. In reference to the experience of the first group, Campéon states:

Elle est le fait d'individus qui, de par leur trajectoire de vie ou leur connaissance, ne parviennent pas à dépasser l'image de la grande vieillesse comme celle d'un «naufrage sénile». Il s'agit généralement $d$ 'individus qui ne présentent pas encore d'incapacités sévères mais qui ont la conviction qu'à partir d'un certain âge (variable selon les personnes) ou d'un degré de handicap, le risque de mal vieillir est trop important. ${ }^{23}$

In reference to the second group, he asserts:

L'appréhension du mal-vieillir, c'est aussi l'appréhension de vieillir seul et d'être ainsi privé, par les circonstances de la vie, d'autrui significatifs qui peuplent leur univers personnel, le colorent et le réchauffent. Autrement dit, d'être privés de ceux et celles qui confirment leur existence et les rassurent sur leur utilité, leur valeur. ${ }^{24}$

In these two instances, the aging imagine a world in which they no longer wish to live. As previously stated, the act of imagination is paramount to individual freedom insofar as futural projection allows one to anticipate a potential experience and then choose from different possibilities of action. Yet, our anticipatory imagination fails when projecting an extreme event such as aging in that it can only be appreciated as an actual embodied experience. We don't understand aging until the first blow. 


\section{The First Blow}

Existentially speaking, one never experiences aging until one is aging. This moment of recognition, the instant when one realizes they are, in fact, living this phenomenon, Améry discusses as a blow:

But without being noticed, the temporal weights have now become distributed in a new way. Grass has been growing over the entire past, which suddenly appears now to be leveled, no longer having any time value at all. Until- one usually discovers it with a blow- the displacement of the quanta of the past, which has continued to take place under the grass, becomes manifest... [emphasis mine] 25

We do not become aware of time as experienced by the aging, until we feel the first blow. We think we can anticipate such an event: the bodily degradation, the loss of autonomy, the dependence on others, etc. Though such language would indicate a grasp or understanding of what it means to age, such grammar fails us. Améry asserts: “The time of which we become aware in aging is not only something we cannot grasp; it is also filled with absurdity, a bitter mockery of every intellectual precision we have aspired to." 26 It is trying to organize that which resists order. Mentally speaking, dates and events are not so easily classified. Physically speaking, after the first blow, the body in its alienation from the world becomes closer to us, so that we become in a sense body. Amery recounts the story of A., a woman who humorously refers to herself as Xanthippe ("yellow horse"), because of the yellow nodes of skin that afflict her face due to old age. She looks in the mirror and sees herself as a stranger. This is not the face she chose. It is unrecognizable to her former self. However, as A. increasingly looks into the mirror and submits herself to the regimented routine of applying eye cream to no avail, she forms a narcissistic relationship to her body, and becomes closer to herself. In this sense, a new ego is forged. Another personage, also referred to as A., complains, "You poor leg, you've been carrying me through a world of streets, mountains, cobblestones, and gas pedals! Now you've been taken from time and work and can't do anymore; you're both tired, just like my heart that won't allow me anymore to go upstairs two steps at a time [emphasis mine]." 27 We only become acquainted with our body [carrying me, my heart, allow me] in aging. Surely a younger person becomes aware of one's appendages after an accident that requires repair, but repair is possible. For the aging, there is no remedy. Amery explicates this reconnaissance with one's body,

We only discover our body and pain in aging. Especially aging, in the way it heaps its burdens upon us more frequently every day. Since in its suffering it no longer transcends itself to dissolve in world and space, this body is just as much a true ego as the stratified time the aging have built up inside themselves. ${ }^{28}$ 
Understanding this new ego formation is important to trying to understand an aging person's opting for suicide. We often hear that A. wasn't in his right mind when the decision took place. Or, that A. wasn't herself. But, what is this fixed identity we appeal to? Améry speaks of the dialectical turn that takes place in aging as it moves towards nothingness. Our body not only becomes more ours, but it becomes more authentic in its internalization of time (this body is just as much a true ego as the stratified time the aging have built up inside themselves). The new aging body, while alienated from its former self, develops a new ego as it tries to reconcile its new balancing of world and time. This body retracts from the world, a world whose language and culture becomes increasingly incomprehensible, yet still attempts to view itself through the eyes of such a society (Yes, the world is retracting, but insofar as this body continues to exist it is still a being-inthe-world and necessarily a being-with-others). As its sense of world diminishes, its sense of time becomes heightened, and it tries to reformulate its ego in the face of this new temporal understanding. Améry notes, "It is true that the ego we carry with us is a creation of society (...) Still, in the act of remembering, we have remodeled and newly interpreted our social ego [Améry's Emphasis]." 29 There is no true identity, in this sense. Our ego can be remolded and newly elucidated. According to Améry, if it is, indeed, possible to speak of an ego, such an identity can only be forged in its removal from the world. For those that still have space in front of them, the formation of an authentic ego is impossible, insofar as their sense of self is constituted through the lens of others. These societal ego formations are consummated through idle talk, everyday parlance that fails to communicate lived temporal experiences; an intimate understanding of time becomes indescribable, as "we have to bring in metaphors from the world of space, if we are to say anything at all about it." 30 Améry speaks of yet another A., a man confined to a dark solitary cell for six months. A.'s spatial confinement, his small cell and more importantly, his withdrawal from the world, work to increase his lived experience of time. Where the world retracts, a sense of time will be heightened. Améry reflects on our existence in space and time, noting,

That by being-in-the-world, by being cast into the world of space, an ego is not yet possible, an ego will only come into being in the struggle against the world and in gentle play with it; that by the time an ego has consolidated itself in one's mind, it is time run by, time without world, and this shadowy ego-in-time has the emotional quality of inert mourning and resignation. ${ }^{31}$

Is this newly devised ego, the product of temporal/spatial redistribution no longer A.? When we say that A. wasn't herself before the leap (a term Amery uses to describe one's disposition right before choosing suicide), what do we mean? Could it be that suicide was an authentic choice according to A's reformulated ego? Can we really try to anticipate and compensate for an 
aging person's loss of autonomy (as per the mission of minister Delauney)? If Améry is correct in postulating that an authentic ego can only be consummated with a retraction from the world, and thus inversely, a manifestation of inner time, is what the aging person is experiencing really a loss of autonomy? On the one hand, yes, in the sense that the bodily degradation of the elderly necessitates dependence on others. However, insofar as those persons still capable of spatial projection intersubjectively communicate via idle talk, any real individual will to action is not possible. Those externalized in space become passive in their capacity to act autonomously, whereas those experiencing the internalization of time have a better understanding of what it means to make an authentic decision. Yet, because the "reasoning" behind an aging person's choice to commit suicide cannot be understood intersubjectively, in that communication relies on some sort of rational symbolic grammatical system, such a decision, though irrational by definition, is chalked up to a medical anomaly: depression. Améry elucidates this point in the following anecdote,

He was dragged to a neurologist who was a friend of his and who wisely said, 'Don't you realize that things like domestic quarrels, tears, and reconciliations belong to vaudeville?' A trifle had escaped the doctor: what is to be called vaudeville and what is to be called tragedy is decided by the author. ${ }^{32}$

The situation vécue before the leap resists communication. The subject cannot be understood intersubjectively. Is this, in part, why Améry chooses to recount the experiences of the aging through the voice of A.? Everyone is A., yet A. is no one. With his first narration, he explains:

We'll call this aging man by the cipher 'A.,' just as we'll designate all those of his comrades in destiny whom from time to time we intend to introduce to our considerations. A: both the most mathematical and abstract specification imaginable and one that leaves to my readers the most extensive free space to think imaginatively and concretely. ${ }^{33}$

A. as "the most mathematical" symbol is objective and thus devoid of subjectivity. Yet, A. is "the most abstract specification imaginable" in that it allows the audience free space to envisage A. as a concrete subject. A. is abstract, yet our mental faculties resist total abstraction as we can only imagine him/her in the form of some solidified identity (we attempt to place order amid disorder). A., as both abstract and concrete, preserves the tension between the subject and its incommensurability with the intersubjective. We can imagine what A. is going through, yet such an experience remains incommunicable. We can anticipate what it will be like to one day age like A., but our imaginative powers will never be able to properly project an event such as aging. Améry invites us to participate in a thought experiment of anticipatory imagination that he knows will fail. 
As previously noted, Amery coins the term anticipatory imagination in his essay On Torture where he provides a phenomenological account of this embodied event. Torture is described as an event so extreme that our imaginative powers can never approach the reality of its actual occurrence. We also noted that the acuteness of such an event was made comparable to that of another embodied experience: that of aging. The parallel made between the two is noted, though not without a sense of uneasiness. One can question whether the experience of torture, particularly when taken within a genocidal context, can be equated with that of old age. Though, it has been suggested that perhaps Améry would not have viewed aging (and its approaching of certain death) as a form of torture had he not, in fact, been the victim of torture (and its imminent threats of death). ${ }^{34}$ That is, in having been tortured, the precariousness of his life was constantly reinforced; he could, at any moment, die. After undergoing such an experience, how could he live with the certainty of death that old age necessarily brings? The tortured person knows he could die, but the aging person has the embodied knowledge that he will die. Though one could continue to speculate on the correlation between aging and torture and whether it is a valid one, what I seek to do here is elucidate on how Amery asserts that our anticipatory imagination fails us in the face of these two extreme events.

Like aging, the realization of torture comes with the first blow. Upon being captured by the Third Reich, Amery states:

I believed to anticipate what was in store for me...so many reports by former Gestapo prisoners had reached my ears that I thought there could be nothing new for me in this area...Thus it was written and thus it would happen...I knew what was coming and they could count on my consent to it. But does one really know?35

He further emphasizes his phenomenological ignorance before the first blow by describing his interrogation by the police. While questioning him for information, they cautioned, "If you don't confess, then it's off to Breendonk, and you know what that means," to which Amery pondered "I knew, and I didn't know (...) And suddenly I felt- the first blow" [Améry's emphasis]. ${ }^{36}$ The first blow makes one cognizant that a border violation is taking place between one's own body and the external world. Améry asserts, "The boundaries of my body are also the boundaries of my self. My skin surface shields me against the external world. If I am to have trust, I must feel on it only what I want to feel [Améry's emphasis]."37 This emphasis on the "want" highlights the non-consensual and non-reciprocal act of the first blow, an act that Améry likens to a rape. Not only is the first blow uninvited and unwelcome, but resistance is not possible. One cannot defend oneself in the instance of this coup, nor can one look elsewhere for assistance:

The first blow brings home to the prisoner that he is helpless, and thus it already contains in the bud everything that is to come. One 
may have known about torture and death in the cell, without such knowledge having possessed the hue of life; but upon the first blow they are anticipated as real possibilities, yes, as certainties. [Améry's emphasis] ${ }^{38}$

With the first blow, one realizes the limit of one's imagination in anticipating an event so extreme, and becomes faced with the "existential consummation of destruction altogether" 39 as a reality. In this moment, one is rendered helpless, as he gains the embodied knowledge that no one will come to his aid. Knowing as a certainty that no one will come to your assistance is detrimental to the phenomenon of torture. Améry suggests,

The expectation of help is as much a constitutional psychic element as is the struggle for existence. Just a moment, the mother says to her child who is moaning from pain, a hot-water bottle, a cup of tea is coming right away, we won't let you suffer so! I'll prescribe you a medicine, the doctor assures it will help you. Even on the battlefield, the Red Cross ambulances find their way to the wounded man. In almost all situations in life where there is bodily injury there is also the expectation of help; the former is compensated by the latter. But with the first blow from a policeman's fist, against which there can be no defense and which no helping hand will ward off, a part of our life ends and it can never again be revived. ${ }^{40}$

In situations of discomfort or pain, we are used to anticipating some form of help. When no one comes to our aid, and when external forces continue to deny our will, we lose "our trust in the world." 41 If I am to have trust, I must feel on [my body] only what I want to feel. This violation from which neither help nor resistance is possible reduces the self to flesh, to a pure body. Améry asserts, "Only in torture does the transformation of the person into flesh become complete. Frail in the face of violence, yelling out in pain, awaiting no help, capable of no resistance, the tortured person is only a body, and nothing else beside that." 42 Is this not the fear of the aging person, confronted by an imminent death from which no assistance is possible? There is no escape from the "ultimate disability, after which no tissue renews itself anymore." 43 Améry dissects the saying "time heals all wounds", insisting that time does no such thing insofar as this wound said to heal no longer exists. He explains: "The wound has become a scab, taken care of by time, and is itself not time any more nor even a spatial exterior, but simply a part of the body, no longer noticing itself and belonging to the world." 44 Those capable of receiving help and healing from their affliction still have trust in the world, a world that is open to them. The aging become more aware of time as the world pulls away from them. The incapacity to resist this retraction reduces the aging body to a pure body (a body with built-up time). The capacity to mediate on time as time is only possible for those who are closed off from the world and its potentialities. Améry 
reiterates this point when he speaks of A., a man we previously mentioned, who finds himself confined to a solitary cell for six months. Whether or not A. is Améry is open to speculation. For even though Amery was not aging at the time of his torture, he does make the point that one who is tortured stays tortured. Thus, it is probable that Améry's evoking A. in On Aging is not only a relived account of his experience but a direct link between the event of torture and aging (in that both extreme events lend themselves to an acute understanding of time). Améry asserts: “[A.] was already half removed from space, and he discovered at that point, once and for all, that lived time in certain circumstances has to compensate for world." 45 As the aging body becomes more of a worldless ego, and as the body no longer mirrors and defines itself in terms of a world (insofar as this world is increasingly retracting), the ego becomes closer to its flesh and its embodiment of gathered up memories. Though alienated from its former conception of self, a new self is formed that is increasingly aware of its physical-temporal condition. Akin to the body that is subject to torture, in that resistance to external forces is not possible, the aging person is likewise unable to call for assistance. We cannot crawl out of our wrinkles or run away from our weakening bones. Améry explains:

This body which is no longer the mediator between the world and us, but cuts us off from world and space with its heavy breathing, painful legs, and the arthritically plagued articulation of our bones, is becoming our prison, but also our last shelter. It is becoming what remains, a shell- the phrase 'mortal remains' probably suggests itself to every aging person who reflects upon what is happening to his or her body- but becoming in the same breath of thought the most extreme human authenticity, since in the end it is what is finally right. [Amery's emphasis] ${ }^{46}$

Améry's emphasis on the it here further points to A's status as a nonsubject. A. is devoid of subjectivity as it no longer participates in a world (with others) that is necessary for one's formation of self. Yet, at the same time, A's transformation to an it permits the manifestation of "the most extreme human authenticity." It is literally down to the barest of bones. This skeletal shell is at once our prison and our last shelter- it is our last prison in that escape from its envelopment is not possible, yet it is our last shelter in that its embrace is all that is left of us. In the extreme events of aging and torture, we are reduced to pure body, alienated from our former self, yet closer to one's true self. This dual experience of body as prison and shelter, felt as a form of both alienation and endearment is not fully realized until the first blow. Améry contends:

The Gestapo tortures. But that was a matter until now for the somebodies who were tortured and displayed their scars at antifascist conferences. That suddenly you yourself are the 
Somebody, is grasped only with difficulty. That, too, is a kind of alienation. ${ }^{4} 7$

That you are now the person being tortured, or that you are now the person who is aging is an occurrence that cannot be anticipated. The incredulity that you yourself are the Somebody experiencing such a phenomenon is met with ambiguity. The equivocality of the situation is illustrated in Améry 's discussion of an aging woman who faithfully carries out her morning routine in front of a mirror. Her reflection is at once hers and not hers. Her face, that is becoming increasingly unrecognizable, no longer projects itself into a world that has expelled her. This retraction increases her inner sense of self until her routine in the mirror is experienced as a "narcissistic melancholy." 48 She becomes resigned to a situation that she cannot escape, yet continues her morning routine in an effort to preserve her former sense of self. She becomes closer to a body that she is no longer able to ignore. The youth are able to forget their bodies insofar as they act as mediators between them and the world. Their bodies, not yet subject to any border violation, can just be out there in the world. However, once the body feels something that it doesn't want to feel, one is forced to acknowledge its separation from the world. This severance induces a breach of trust; Améry states that with the first blow, one loses "trust in the world." Yet, before describing this dissociation from the world as resulting in a loss of trust, Améry summarily discusses whether what is felt is a loss of dignity. He states,

Not much is said when someone who has never been beaten makes the ethical and pathetic statement that upon the first blow the prisoner loses his dignity. I must confess that I don't know exactly what that is: human dignity. One person thinks he loses it when he finds himself in circumstances that make it impossible for him to take a daily bath. Another believes he loses it when he must speak to an official in something other than his native language. 49

Though Améry claims to not know what human dignity is, it is clear that he believes it to be an affair of ethics (ethical and pathetic statement). Insofar as he is trying to be merely descriptive of his experiences via an existential and phenomenological analysis, does he believe ethics has no place in his project? Is he only concerned with the recounting of embodied experiences and not the moral evaluation of them? What is noteworthy about his description of human dignity is its subjective quality (one person thinks...another person believes). It is the subjective nature of one's condition before the leap that interests Améry insofar as it resists intersubjective understanding. There is no universal "before the leap" experience, much like there is no agreed upon definition of human dignity. It is the incommunicability of one's loss of dignity that interests me insofar as current debates on assisted suicide in France focus on comment mourir dans la dignité. That is, whether or not assisted suicide should be legalized 
depends on whether or not such assistance would allow one to better die with dignity. La loi Leonetti and subsequent revisions promise "assistance médicalisée pour terminer sa vie dans la dignité," 50 yet do not allow aging persons access to "toute pastille létale qui permettrait une mort douce". Being able to refuse therapeutic intervention, or opting to discontinue medical treatment are ways to preserve one's dignity, while access to assisted suicide is deemed indignant. How is dignity being defined here? How can a law guarantee one's right to die with dignity if such a concept resists universality? Is someone able to properly explain why their being allowed une mort douce via assisted suicide equates to dying with dignity? In his book Le fin mot de la vie: Contre le mal mourir en France, Le Guay views assisted suicide as a "soft barbaric" reply to the conditions of aging persons in France. As previously noted, he believes the French population is largely in favor of assisted suicide because of their fear of dying in hospitals. He states that one should not die alone, silenced in a hospital, but should be able to engage in a sort of "last dialogue" with others. He puts an emphasis on the importance of exchanging words at the end of one's life, but if one truly wants to die, aren't such thoughts 'before the leap' incommunicable? It is the failure of the subjective to be understood intersubjectively that is missing from current debates on assisted suicide in France. As Améry makes clear in On Aging, the event of aging, the moving towards annihilation, is absurd and met with ambiguity as this new ego formation tries to reconcile with its former self. We cannot anticipate how we will react to the shift in balance between world and time that creates this reformulated ego. Furthermore, when we meet this occurrence, we won't be able to make it accessible to the outside world, as we are only equipped with the language of idle talk that perpetuates the public space. The law in France tries to codify and rationally justify how to die with dignity, when the pure body confronting death resists reason. How can France better respect the right of the person to die with dignity? Deschavanne and Tavoillot assert:

L'ultime souhait de l'individu est de mourir en individu : ne pas se trouver, dès avant la mort, réduit à son corps, considéré comme un 'cadavre vivant'. La force des débats sur l'euthanasie, sur l'accompagnement des mourants le montrent. Tout comme d'ailleurs ceux sur le suicide des vieux. Si la question de l'entrée dans la vie s'est considérablement complexifiée, que dire de celle de la sortie? Nous oscillons là entre le fatalisme du 'il n'y a plus rien à faire' et l'illusion que la 'science peut tout', sans voir qu'entre la mort subie et la mort déniée, il y a une immense espace: celui de la mort aménagée. 51

They seem to believe that it is possible to die as an individual without being reduced to a state of pure body. What they label a "cadavre vivant", Améry likens to "mortal remains", yet these remains are both prison and last shelter. My reduction to pure body is me at my most individual insofar as I 
retract from a world where my former ego was constructed through the eyes of others. This last shelter is me at my most authentic as it experiences an internalization of time. Deschavanne and Tavoillot call for a space between la mort subie and la mort deniée: la mort aménagée. They appeal to a politics of aging that takes into account the modern historical context in which people are aging. What does this arrangement of death look like? How can we newly adapt to our Being-towards-death?

Though he offers no clear solutions, Améry's existential and phenomenological account of aging, coupled with his critical analysis on suicide, offer important insights into how to better understand the current debate regarding assisted suicide in France. His notion of anticipatory imagination and its eventual failure in projecting extreme events such as aging adds a new element to thinking about future bioethics legislation.

${ }^{1}$ Améry, At the Mind's Limits: Contemplations By A Survivor On Auschwitz and Its Realities, trans. Sidney Rosenfeld and Stella P. Rosenfeld, Bloomington and Indianapolis: Indiana University Press, 1980, p. 25.

2 Améry, On Aging: Revolt and Resigniation, trans. John D. Barlow, Bloomington and Indianapolis: Indiana University Press, 1994, p. xix.

${ }^{3}$ Améry, On Aging: Revolt and Resigniation xviii

4 http:/ / www.rtl.fr/ actu/le-suicide-des-personnes-agees-environ-3-000-cas-par-an-et-un-tiers-dessuicides- 7767332731

5 http:// www.europe1.fr/ faits-divers/ main-dans-la-main-les-amants-du-lutetia-voulaient-mourirensemble-1719805

6 http:// www.europe1.fr/ faits-divers/ main-dans-la-main-les-amants-du-lutetia-voulaient-mourirensemble-1719805

${ }^{7}$ Améry, On Aging: Revolt and Resigniation, 17

${ }^{8}$ Améry, On Aging: Revolt and Resigniation, 17

${ }_{9}^{9}$ Améry, On Aging: Revolt and Resigniation, 15-16

10 J ean Amery's On Suicide: A Discourse on Voluntary Death, trans. J ohn D. Barlow, Bloomington and Indianapolis: Indiana Univ. Press, 1999 was translated from the German Hand an sich legen which literally means to "to lay hand on oneself".

11 http:/ / www. lefigaro.fr/ vox/ societe/ 2014/ 11/ 24/ 31003-20141124ARTFIG00081-fin-de-vie-mourirvraiment-dans-la-dignite.php

12 Friedrich Nietzsche, Thus Spoke Zarathustra, London:Penguin, 1972, prologue

${ }^{13}$ Améry, At the Mind's Limits, 25.

14 http:// www.rtl.fr/ actu/ trois-suicides-de-personnes-agees-en-deux-jours-la-ministre-s-inquiete7751486346 
${ }^{15}$ Améry, On Suicide, xiv-xv

16 http:// www.rtl. fr/ actu/ le-suicide-des-personnes-agees-environ-3-000-cas-par-an-et-un-tiers-dessuicides- 7767332731

${ }_{17}$ Deschavanne and Tavoillot, Philosophie des âges de la vie, Paris: Bernard Grasset, 2007, p. 496.

${ }^{18}$ Deschavanne and Tavoillot, Philosophie des âges de la vie, 494

${ }^{19}$ Deschavanne and Tavoillot, Philosophie des âges de la vie, 499-500

$20 \mathrm{http} / / /$ www.rtl.fr/ actu/ suicides-de-couples-d-octogenaires-les-personnes-agees-ont-peur-de-malmourir-dit-une-philosophe-7767380565

${ }^{21}$ Ibid

22 Nietzsche, Beyond Good and Evil, Cambridge: Cambridge Univ. Press, 2001, p. 109.

${ }^{23}$ Campéon, "Se suicider au grand âge : I'ultime recours à une vieillesse déchue ?", Interrogations No14: Le Suicide, J une 2012.

${ }^{24}$ Campéon, "Se suicider au grand âge : I'ultime recours à une vieillesse déchue ?"

${ }^{25}$ Améry, On Aging, 10

${ }^{26}$ Améry, On Aging 8

${ }^{27}$ Améry, On Aging 40

${ }^{28}$ Améry, On Aging 42

${ }^{29}$ Améry, On Aging 49

${ }^{30}$ Améry, On Aging 22

${ }^{31}$ Améry, On Aging 23

${ }^{32}$ Améry, On Suicide, 9

${ }^{33}$ Améry, On Aging, 2

${ }^{34}$ Here I think of Régine Waintrater's translator's introduction to the French version of On Aging [Du Vieillissement].

${ }^{35}$ Améry, At the Mind's Limits, 25

${ }^{36}$ Améry, At the Mind's Limits, 26

${ }^{37}$ Améry, At the Mind's Limits, 28

${ }^{38}$ Améry, At the Mind's Limits, 27

${ }^{39}$ Améry, At the Mind's Limits, 28

${ }^{40}$ Améry, At the Mind's Limits, 28-29

${ }^{41}$ Améry, At the Mind's Limits, 32

${ }^{42}$ Améry, At the Mind's Limits, 33

${ }^{43}$ Améry, On Aging, 26 
${ }^{44}$ Améry, On Aging, 26

${ }^{45}$ Améry, On Aging, 23

${ }^{46}$ Améry, On Aging, 35

${ }^{47}$ Améry, At the Mind's Limits, 39

48 Améry, On Aging, 32

49 Améry, At the Mind's Limits, 27

50 http:// www. lemonde. fr/ societe/ article/ 2016/ 01/ 27/ fin-de-vie-ce-que-va-changer-la-nouvelleloi-claeys-leonetti_4854266_3224.html

51 Deschavanne and Tavoillot, Philosophie des âges de la vie, Paris: Bernard Grasset, 2007, p. 505. 